\title{
Exogenous enzymes improve performance and carcass traits of feedlot cattle fed high-grain diet
}

\author{
Mikael Neumann ${ }^{1}$, Guilherme Fernando Mattos Leão ${ }^{2^{*}}$ (iD), Egon Henrique Horst ${ }^{3}$ (iD), \\ Osmair Flavio Stuani ${ }^{4}$, Cleiton Pagliari Sangali ${ }^{5}$, Ricardo Castilho ${ }^{4}$
}

\author{
${ }^{1}$ Universidade Estadual do Centro-Oeste, Guarapuava, PR, Brasil. \\ ${ }^{2}$ Universidade Federal do Paraná, Programa de Pós-graduação em Zootecnia, Curitiba, PR, Brasil. \\ ${ }^{3}$ Universidade Estadual de Londrina, Programa de Pós-graduação em Ciência Animal, Londrina, PR, Brasil. \\ ${ }^{4}$ Safeeds, Cascavel, PR, Brasil. \\ ${ }^{5}$ Centro Universitário Integrado, Campo Mourão, PR, Brasil.
}

\begin{abstract}
The objective of this study was to evaluate the effects of supplementation of two different enzymatic complexes, fibrolytic (NSPases) or amylolytic (EXP3066) enzymes, on growth performance, digestibility, behavior, and carcass characteristics of feedlot cattle. Thirty-six $1 / 2$ Angus yearling bulls with an average initial weight of $391 \pm 5.0 \mathrm{~kg}$ were used in this experiment blocked by weight in a completely randomized design divided in three treatments: control, NSPases, and EXP3066. The basal diet was composed of $85 \%$ whole corn grain and $15 \%$ nucleus. NSPases increased average daily gain on days 63 and 84 , and gain:feed ratio on days 42,63 , and 84 . Total carcass weight and carcass daily gain were improved by $4.8 \%$ and up to $6.0 \%$ with EXP3066 and NSPases supplementations, respectively. The group that received NSPases supplementation showed even greater carcass feed efficiency when compared with animals in the control group. There was an increase in apparent dry matter digestibility and a decrease of fecal whole grain residual percentage with enzyme supplementation. Enzyme supplementation affected hot carcass weight and EXP3066 provided greater values for ribeye area and marbling compared with control. Exogenous enzymes improve performance and carcass traits in feedlot cattle fed high-grain diet.
\end{abstract}

Key Words: amylase, corn, high-energy diet, non-starch polysaccharides, xylanase

\section{Introduction}

Energy-dense diets (high grain diets) for cattle, although in Brazil is not a common practice (Millen et al., 2009), is becoming more present in feedlot due to the improvements observed on performance, carcass characteristics, and the convenience for feedlot operations (Neumann et al., 2015).

However, Brazilian corn has a predominance of vitreous endosperm, being a corn of low degradability in the ruminal environment and with lower total starch digestibility as shown by Correa et al. (2002), and this could decrease performance. Therefore, tools that optimize corn starch use are necessary.

In this context, exogenous enzymes may be an important tool to increase the digestibility of corn grain and improve feed efficiency of feedlot cattle. Numerous studies, however,

Received: November 27, 2017

Accepted: May 1, 2018

*Corresponding author: gfleao@hotmail.com

Copyright (C) 2018 Sociedade Brasileira de Zootecnia. This is an Open Access article distributed under the terms of the Creative Commons Attribution License (http://creativecommons.org/licenses/by/4.0/), which permits unrestricted use, distribution, and reproduction in any medium, provided the original work is properly cited. have shown inconsistent results regarding the use of enzymes on animal performance (Beauchemin et al., 1995, 1999; Hristov et al., 2000; DiLorenzo et al., 2011; Oliveira et al., 2015). The lack of benefits when supplementing exogenous enzymes as well as the inconsistency of responses can mainly be attributed to differences in activity and characteristics of supplemented enzymes in each study. Moreover, physical and chemical properties of the substrates may also play a role (Meale et al., 2014; Tadele and Animut, 2015).

Therefore, the objective of this study was to evaluate the effects of the supplementation of two different enzymatic complexes: one composed of fibrolytic enzymes with action on non-starch polysaccharide (NSPases) and an extract with a predominant activity of amylase (EXP3066) on growth performance, digestibility, behavior, and carcass characteristics of feedlot yearling bulls fed an energy-dense diet.

\section{Material and Methods}

The experiment was conducted in Guarapuava city, Paraná, Brazil $\left(25^{\circ} 23^{\prime} 02^{\prime \prime} \mathrm{S}, 5^{\circ} 29^{\prime} 43^{\prime \prime} \mathrm{W}\right.$, and $1100 \mathrm{~m}$ altitude) from February to May, 2015. 
All experimental procedures were submitted and approved (case no. 001/2015) by the Animal Care and Use Committee (CEUA).

Thirty-six $1 / 2$ Angus bulls sourced from a single herd, with initial body weight (BW) of $391 \pm 5 \mathrm{~kg}$ and averaging 12 months of age, were used in this experiment. The animals were housed in 18 semi-covered confinement pens $\left(15 \mathrm{~m}^{2}\right)$, with concrete feeders, and float-regulated waterers.

Bulls were dewormed and allotted according to BW and body condition in a completely randomized design consisting of three treatments with six replicates. Each replicate consisted of a pen with two animals. Experimental treatments were grouped as follows: control - diet without the use of enzymes; EXP3066 - control diet supplemented with $10 \mathrm{~g}$ of EXP3066 extract per animal per day; and NSPases - control diet supplemented with $10 \mathrm{~g}$ of NSPases complex per animal per day.

The enzymatic extract EXP3066 was obtained by the fermentation of the fungi Aspergillus oryzae and Trichoderma viride and the bacteria Bacillus subtilis and contained a predominant activity of amylase (Table 1). The NSPases complex was obtained by the fermentation of the fungi Aspergillus niger and Trichoderma reesei with predominant activity of xylanase (JBS-United; Sheridan, IN, EUA). The dose used followed manufacture indication.

Activities of xylanase, cellulase, $\beta$-glucanase, mannanase, $\alpha$-galactosidase, and amylase from the products were determined by the 3,5-dinitrosalicylic acid method and expressed in international units per grams (IU/g), in which $1 \mathrm{IU}$ of activity corresponds to the amount of enzyme hydrolyzing $1 \mathrm{mmoL}$ of the glycosidic linkages of the substrate per minute.

The experiment consisted of a 10-day adaptation period to the diets and housing, followed by an 84-day experimental period. On the first three days of the adaptation period, animals received $1.2 \%$ of BW of concentrated mix ( $85 \%$ of whole corn grain plus $15 \%$ of the protein-vitaminmineral premix) and corn silage ad libitum. From day 4 to 7 , animals received $1.6 \%$ of $\mathrm{BW}$ of the concentrated mix and corn silage ad libitum. On day 8, the corn silage supply was interrupted, and the animals received only the concentrated mix ad libitum with daily adjustments.
The control diet was composed of $85 \%$ whole corn grain and $15 \%$ of protein-vitamin-mineral premix, formulated to sustain a $1.5 \mathrm{~kg} /$ day average daily gain (ADG), according to NRC (2000). The products containing the exogenous enzymes (EXP3066 and NSPases) were used in a topdressed form in the diet at feeding time to ensure accuracy and intake of the prescribed dosages.

The protein-vitamin-mineral premix was prepared in the commercial feed mill Cooperativa Agraria (Guarapuava, Paraná, Brazil), formulated with a soybean meal base along with wheat meal, malt byproduct, limestone, calcium phosphate, urea, salt, mineral and vitamin premix, monensin, and virginiamycin and was presented in pelleted form.

Bulls were fed twice daily (06:00 and 17:00 h), and intakes were recorded daily by subtracting the difference between the amount offered and orts from the previous day. Feed was adjusted daily and offered ad libitum by ensuring a $10 \%$ refusal every day on a dry matter (DM) basis.

Diet samples from each treatment were collected during the experimental period (Table 2). Composite feed samples were dried in a forced-air oven at $55^{\circ} \mathrm{C}$ for $72 \mathrm{~h}$ and sequentially ground in a Wiley mill using a 1-mm diameter sieve. Samples were analyzed for DM, inorganic matter, crude protein (CP), and fat following AOAC (1995)

Table 2 - Ingredient and chemical composition of the control diet

\begin{tabular}{lc}
\hline Ingredient & $\%$ \\
\hline Whole corn grain & 85 \\
Protein-vitamin-mineral premix ${ }^{1,2}$ & 15 \\
Analyzed composition & $\% \mathrm{DM}$ \\
DM (\%) & 90.06 \\
CP & 13.04 \\
Ashes & 3.090 \\
Fat & 3.300 \\
ADF & 6.880 \\
NDF & 18.25 \\
Starch & 57.74 \\
TDN & 81.59
\end{tabular}

DM - dry matter; CP - crude protein; NDF - neutral detergent fiber; ADF - acid detergent fiber; TDN - total digestible nutrients.

${ }^{1}$ Premix composition: DM, 90.22\%; CP, 42.23\%; NDF, 24.61\%; ADF, $12.28 \%$; inorganic matter, $16.31 \%$; fat, 2.95 ; TDN, $69.70 \%$; phosphorus, $1.11 \%$; calcium $2.77 \%$; monensin, $75 \mathrm{mg} / \mathrm{kg}$; and virginiamycin, $75 \mathrm{mg} / \mathrm{kg}$.

${ }^{2}$ Guaranteed levels per kg of premix: vitamin A, $42000 \mathrm{IU}$; vitamin D3, $5400 \mathrm{IU}$ vitamin E, $225 \mathrm{IU}$; biotin, $9 \mathrm{mg}$; sulfur, $2.1 \mathrm{~g}$; magnesium, $0.36 \mathrm{~g}$; sodium, $4.68 \mathrm{~g}$; cobalt, $3 \mathrm{mg}$; copper, $54 \mathrm{mg}$; chrome, $0.9 \mathrm{mg}$; fluorine, $23.4 \mathrm{mg}$; iodine, $3.3 \mathrm{mg}$; manganese, $87 \mathrm{mg}$; selenium, $1.05 \mathrm{mg}$; and zinc, $216 \mathrm{mg}$.

Table 1 - Enzymatic activity of EXP3066 extract and NSPases complex

\begin{tabular}{lcccccc}
\hline \multirow{2}{*}{ Complex } & \multicolumn{5}{c}{ Enzymatic activity $(\mathrm{IU} / \mathrm{g})^{1}$} \\
\cline { 2 - 7 } & Xylanase & Cellulase & $\beta$-glucanase & $\beta$-mannanase & $\alpha$-galactosidase & \multicolumn{1}{c}{ Amylase } \\
\hline EXP3066 & 9 & - & - & - & 107 & 11 \\
NSPases & 3117 & 2870 & 2210 & 372 & 21 \\
\hline
\end{tabular}

${ }^{1} \mathrm{Xylanase}$ : tested in $\mathrm{pH} 4.5$ at $40{ }^{\circ} \mathrm{C}$; Cellulase: tested in $\mathrm{pH} 4.8$ at $50{ }^{\circ} \mathrm{C} ; \beta$-glucanase, $\beta$-mannanase, and Amylase: tested in pH 5.0 at $40{ }^{\circ} \mathrm{C} ; \alpha$-galactosidase: tested in pH 5.5 at $37^{\circ} \mathrm{C}$. 
procedures. The neutral detergent (NDF) and acid detergent (ADF) fiber fractions were analyzed using thermo-stable $\alpha$-amylase according to Van Soest et al. (1991) and Goering and Van Soest (1970), respectively. The estimated total digestible nutrients (TDN) were obtained according to Weiss et al. (1992).

Starch analysis was performed according to the methodology described by Hendrix (1993). This method is based on the hydrolysis of starch contained in the sample, after extraction of soluble carbohydrates with successive $80 \%$ alcohol washes and colorimetric analysis of reducing sugars (glucose), with subsequent conversion of the results for starch.

Animals were weighed at trial initiation, days 21, 43, and 64, and at the end of the experiment, after a 12-h fasting period, to determine ADG. Amount of feed offered and orts from the previous day were weighed daily to determine dry matter intake (DMI) and gain to feed ratio (G:F).

Total carcass weight gain (CWG), carcass daily gain (CDG), and carcass feed efficiency (CG:F) were calculated using ADG, DMI, and hot carcass weight (HCW). Carcass total weight gain was calculated as the difference between $\mathrm{HCW}$ and initial carcass weight (iCW), which was estimated considering an initial carcass yield of $50 \%$ (iCW $=$ initial $\left.\mathrm{BW}^{*} 0.50\right)$. Carcass daily gain was calculated for the 89 days of confinement $(\mathrm{CDG}=\mathrm{CWG} \div 89)$. Carcass feed efficiency was represented by the ratio between $\mathrm{CDG}$ and DMI (CG:F $=$ DMI $\div$ CDG).

A behavioral analysis was performed for 48 continuous hours on day 42 of the experiment. Observations were performed by nine individuals per shift in a 6-h rotation cycle. Readings were collected every $3 \mathrm{~min}$. Behavioral data included time spent eating (hours per day and number of times per day), drinking water (hours per day and number of times per day), ruminating (hours per day), and resting (hours per day), following adapted methodology from Johnson and Combs (1991). The events of xylophagy (behavior that the animal tries to consume wood to stimulate salivation in response to a low ruminal $\mathrm{pH}$ ), and solid and liquid excretions per day were also evaluated.

Between 42 and 44 days of the experimental period, over two consecutive days, total fecal production was collected from the ground of the experimental units to calculate apparent total tract DM digestibility (DMD). Total fecal matter was weighed and sampled each six hours and stored in a freezer at $-18{ }^{\circ} \mathrm{C}$ until further analysis. A sample from the composite feed and orts from the previous day were also collected.

The DM, CP, and starch concentration in the composite feed, orts, and feces from each experimental unit were determined using the same procedures from the feed analysis. Apparent DMD was calculated using the following equation: DMD $(\%)=[(\mathrm{DM}$ consumed $-\mathrm{DM}$ excreted $) \div$ DM consumed] $\times 100$.

The same formula was used to calculate the CP and starch digestibility, multiplying the consumed feed, orts, and fecal matter by the specific proportions of each variable as obtained from the laboratory.

A 300-g feces sub-sample of each experimental unit was collected at the end of each 6-h shift, washed through a 5-mm sieve to capture whole corn kernels from the stool in the sieve. Following washing, whole corn kernels were counted to determine the number of excreted whole grains (NEWG). Afterwards, the material was dried in a forced-air oven at $55^{\circ} \mathrm{C}$ for $72 \mathrm{~h}$ and subsequently weighed to obtain the weight of fecal whole grain. Additionally, whole corn kernels in ten 100-g sub-samples of composite feed were counted to determine the number of consumed whole grain (NCWG). The fecal whole grain residual percentage (RWG) was calculated from the NEWG and NCWG data using the following equation: RWG $(\%)=100-100 *[(\mathrm{NCWG}-\mathrm{NEWG}) \div \mathrm{NCWG}]$.

At the end of the experimental period, ribeye area (REA) and fat thickness were evaluated using an ultrasound machine (Aloka SSD-500 Vet) with a $17 \mathrm{~cm}, 3.5 \mathrm{MHz}$ probe. Measurements were made between the 12th and 13th rib transversally to the longissimus dorsi according to Herring et al. (1994). For REA measurements, a ratio was calculated as the relationship between the height and width of the ribeye. Ultrasound images were interpreted by a laboratory responsible for data quality (Designer Genes Technology) through the "BIA/DGT Brazil" software. Marbling was evaluated according to the existence of fat deposits in the longissimus dorsi and scored in a 1 (nonexistent) to 5 (excessive) scale, adapted from Müller (1987).

After a 12-h fasting period, all animals were weighed to obtain the final $\mathrm{BW}$ and transported to a commercial meat plant located $5 \mathrm{~km}$ away. Slaughter was performed according to plant protocols and state laws. All carcasses were evaluated individually according to Müller (1987) to determine HCW, carcass yield, carcass length, arm length and circumference, top round diameter, and fat thickness (longissimus dorsi, round, rib cage, and chuck).

Performance, digestibility, behavior, and carcass characteristics data were subjected to analysis of variance (ANOVA) using the PROC GLM of SAS (Statistical Analysis System, version 6.09), and means were compared with Tukey adjustment for $\mathrm{P}<0.05$.

The following statistical model was used:

$$
\mathrm{Y}_{\mathrm{i}}=\mu+\mathrm{T}_{\mathrm{i}}+\mathrm{E}_{\mathrm{i}} \text {, }
$$

R. Bras. Zootec., 47:e20170308, 2018 
in which $\mathrm{Y}_{\mathrm{i}}=$ response variable; $\mu=$ overall average of all observations; $\mathrm{T}_{\mathrm{i}}=$ treatment effect $(\mathrm{i}=1$ to 3$)$; and $\mathrm{E}_{\mathrm{i}}=$ residual random error.

For performance and digestibility variables, each pen (containing two animals) represented one experimental unit. For the remaining variables, one experimental unit was represented by each animal individually.

\section{Results}

The supplementation with exogenous enzymes did not affect $(\mathrm{P} \geq 0.98)$ DMI (Table 3). However, the addition of the complex NSPases to the diet improved the ADG on days $63(\mathrm{P}=0.01)$ and $84(\mathrm{P}=0.04)$, and the $\mathrm{G}: \mathrm{F}$ on days 42 , 63 , and $84(\mathrm{P} \leq 0.07)$. Considering the total period of the experiment, there was an improvement of $11.4 \%$ (1.60 vs. $\left.1.44 \mathrm{~kg} \mathrm{day}^{-1}\right)$ for ADG and $11.7 \%$ (0.200 vs. $\left.0.179 \mathrm{~g} \mathrm{~kg}^{-1}\right)$ for G:F with the supplementation of the complex NSPases, when compared with the control diet. The variables $\mathrm{CWG}$ and $\mathrm{CDG}$ were improved $(\mathrm{P}=0.05)$ by $4.8 \%$ and up to $6.0 \%$ with the supplementation of EXP3066 and NSPases, respectively. The group NSPases supplementation showed even greater $(\mathrm{P}=0.07) \mathrm{CG}: \mathrm{F}$ values $\left(0.144 \mathrm{~g} \mathrm{~kg}^{-1}\right)$ when compared with control animals $\left(0.136 \mathrm{~g} \mathrm{~kg}^{-1}\right)$.

Table 3 - Performance of feedlot finishing yearling bulls fed an energy-dense diet supplemented with exogenous enzymes

\begin{tabular}{|c|c|c|c|c|c|}
\hline \multirow{2}{*}{ Item } & \multicolumn{3}{|c|}{$\operatorname{Diet}^{1}$} & \multirow{2}{*}{ SEM } & \multirow{2}{*}{ P-value } \\
\hline & Control & EXP3066 & NSPases & & \\
\hline \multicolumn{6}{|l|}{$\overline{\mathrm{ADG}(\mathrm{kg})}$} \\
\hline Days 0-21 & 1.70 & 1.69 & 1.73 & 0.02 & 0.84 \\
\hline Days 0-42 & 1.51 & 1.54 & 1.67 & 0.02 & 0.15 \\
\hline Days 0-63 & $1.51 \mathrm{~b}$ & $1.60 \mathrm{ab}$ & $1.73 \mathrm{a}$ & 0.02 & 0.01 \\
\hline Days 0-84 & $1.44 \mathrm{~b}$ & $1.51 \mathrm{~b}$ & $1.60 \mathrm{a}$ & 0.02 & 0.04 \\
\hline \multicolumn{6}{|l|}{ DMI (kg/day) } \\
\hline Days 0-21 & 8.08 & 8.00 & 7.99 & 0.87 & 0.98 \\
\hline Days $0-42$ & 7.96 & 7.91 & 7.88 & 0.73 & 0.99 \\
\hline Days 0-63 & 7.92 & 7.97 & 7.94 & 0.67 & 0.99 \\
\hline Days 0-84 & 8.03 & 8.09 & 8.01 & 0.73 & 0.98 \\
\hline \multicolumn{6}{|l|}{$\mathrm{G}: \mathrm{F}(\mathrm{g} / \mathrm{kg})$} \\
\hline Days 0-21 & 0.211 & 0.211 & 0.217 & 0.05 & 0.27 \\
\hline Days $0-42$ & $0.189 b$ & $0.195 \mathrm{~b}$ & $0.212 \mathrm{a}$ & 0.01 & 0.06 \\
\hline Days 0-63 & $0.191 \mathrm{~b}$ & $0.200 \mathrm{ab}$ & $0.218 \mathrm{a}$ & 0.01 & 0.05 \\
\hline Days $0-84$ & $0.180 \mathrm{~b}$ & $0.187 \mathrm{ab}$ & $0.201 \mathrm{a}$ & 0.02 & 0.07 \\
\hline CWG (kg) & $94.90 \mathrm{~b}$ & $99.50 \mathrm{a}$ & $100.6 \mathrm{a}$ & 0.92 & 0.05 \\
\hline CDG (kg/day) & $1.091 \mathrm{~b}$ & $1.143 \mathrm{a}$ & $1.156 \mathrm{a}$ & 0.02 & 0.05 \\
\hline CG:F (g/kg) & $0.136 \mathrm{~b}$ & $0.141 \mathrm{ab}$ & $0.144 \mathrm{a}$ & 0.01 & 0.07 \\
\hline
\end{tabular}

ADG - average daily gain; DMI - dry matter intake; G:F - gain to feed ratio (feed efficiency); CWG - carcass total weight gain; CDG - carcass daily gain; CG:F carcass feed efficiency; SEM - standard error of the mean.

${ }^{1}$ Diets = control: diet without the use of enzymes; EXP3066: enzymatic extract (Aspergillus oryzae $\times$ Trichoderma viride $\times$ Bacillus subtilis) with a predominant activity of amylase; NSPases: enzymatic complex (Enspira ${ }^{\mathbb{B}}$; JBS-United; Sheridan, IN, EUA) composed of enzymes with action on non-starch polysaccharides. $\mathrm{a}, \mathrm{b}$ - Means followed by different letters in the same row are significantly different by Tukey test $(\mathrm{P} \leq 0.07)$.
There was no effect $(\mathrm{P} \geq 0.33)$ of the use of enzymes on apparent starch and CP digestibility (Table 4). However, the supplementation with EXP3066 and NSPases promoted greater $(\mathrm{P}=0.05)$ values (87.52 and $87.31 \%$, respectively) of apparent DM digestibility, compared with the control diet $(84.15 \%)$. There was also an effect $(\mathrm{P} \leq 0.02)$ of the supplementation on the presence of fecal whole corn (number $\mathrm{kg}^{-1}$ and $\mathrm{g} \mathrm{kg}^{-1}$ of fecal matter), in which the lowest values were found in animals receiving EXP3066. The supplementation with enzymes reduced $(\mathrm{P}<0.01)$ the fecal whole grain residual percentage, with lower values observed for EXP3066 supplementation (2.25\%) when compared with NSPases $(2.72 \%)$, both lower than the percentage observed in control group (4.11\%).

There was no effect $(\mathrm{P} \geq 0.20)$ of the inclusion of exogenous enzymes in the diet on time spent drinking water, resting, or number of solid and liquid excretions. However, animals fed diet supplemented with NSPases complex spent less $(\mathrm{P}=0.02)$ time eating $\left(1.83\right.$ vs. $\left.2.60 \mathrm{~h} \mathrm{day}^{-1}\right)$ compared with non-supplemented animals, and more $(\mathrm{P}=0.04)$ time ruminating (1.92 vs. $0.94 \mathrm{~h} \mathrm{day}^{-1}$ ), compared with animals fed diet supplemented with EXP3066 (Table 5). Animals from EXP3066 group showed lower $(\mathrm{P}=0.04)$ xylophagy events (5.7 times day $^{-1}$ ) compared with animals from control and NSPases groups.

Regarding carcass characteristics, there was an effect $(\mathrm{P}=0.04)$ of both enzymatic treatments on $\mathrm{HCW}$, in which the greatest values $(294.7$ and $296.0 \mathrm{~kg}$ for EXP3066 and NSPases, respectively) were observed in animals fed diet supplemented with exogenous enzymes (Table 6). The supplementation with EXP3066 also increased REA

Table 4 - Apparent dry matter, crude protein, and starch digestibilities and analysis of fecal whole grain of feedlot finishing yearling bulls fed an energy-dense diet supplemented with enzymes

\begin{tabular}{|c|c|c|c|c|c|}
\hline \multirow{2}{*}{ Item } & \multicolumn{3}{|c|}{$\operatorname{Diet}^{1}$} & \multirow{2}{*}{ SEM } & \multirow{2}{*}{ P-value } \\
\hline & Control & EXP3066 & NSPases & & \\
\hline \multicolumn{6}{|l|}{ Digestibility (\%) } \\
\hline Dry matter & $84.15 b$ & $87.52 \mathrm{a}$ & $87.31 \mathrm{a}$ & 0.41 & 0.05 \\
\hline Crude protein & 78.10 & 81.44 & 81.05 & 0.67 & 0.33 \\
\hline Starch & 92.38 & 93.35 & 92.54 & 0.34 & 0.69 \\
\hline \multicolumn{6}{|l|}{ Fecal whole grain } \\
\hline $\mathrm{n} / \mathrm{kg}$ of fecal matter & $136.7 \mathrm{a}$ & $78.9 \mathrm{~b}$ & 98.9ab & 5.38 & 0.02 \\
\hline $\mathrm{g} / \mathrm{kg}$ of fecal matter & $54.51 \mathrm{a}$ & $28.78 b$ & $36.47 \mathrm{ab}$ & 1.99 & 0.01 \\
\hline $\begin{array}{l}\text { Fecal whole grain } \\
\text { residual percentage (\%) }\end{array}$ & $4.11 \mathrm{a}$ & $2.25 \mathrm{c}$ & $2.72 \mathrm{~b}$ & 0.21 & $<0.01$ \\
\hline
\end{tabular}

SEM - standard error of the mean.

${ }^{1}$ Diets = control: diet without the use of enzymes; EXP3066: enzymatic extract (Aspergillus oryzae $\times$ Trichoderma viride $\times$ Bacillus subtilis) with a predominant activity of amylase; NSPases: enzymatic complex (Enspira ${ }^{\circledR}$; JBS-United; Sheridan, IN, EUA) composed of enzymes with action on non-starch polysaccharides. $a, b$ - Means followed by different letters in the same row are significantly different by Tukey test $(\mathrm{P} \leq 0.05)$. 
Table 5 - Behavioral evaluation of feedlot finishing yearling bulls fed an energy-dense diet and supplemented with enzymes

\begin{tabular}{|c|c|c|c|c|c|}
\hline \multirow{2}{*}{ Item } & \multicolumn{3}{|c|}{$\operatorname{Diet}^{1}$} & \multirow{2}{*}{ SEM } & \multirow{2}{*}{ P-value } \\
\hline & Control & EXP3066 & NSPases & & \\
\hline \multicolumn{6}{|c|}{$\mathrm{h} /$ day } \\
\hline Eating & $2.60 \mathrm{a}$ & $2.12 \mathrm{ab}$ & $1.83 \mathrm{~b}$ & 0.10 & 0.02 \\
\hline Drinking water & 0.30 & 0.43 & 0.42 & 0.04 & 0.44 \\
\hline Ruminating & $1.14 \mathrm{ab}$ & $0.94 b$ & $1.92 \mathrm{a}$ & 0.14 & 0.04 \\
\hline Resting & 19.97 & 20.54 & 19.81 & 0.17 & 0.24 \\
\hline \multicolumn{6}{|c|}{ Number of times/day } \\
\hline Eating & 20.50 & 21.20 & 16.50 & 1.06 & 0.20 \\
\hline Drinking water & 10.70 & 8.50 & 8.60 & 0.77 & 0.43 \\
\hline Xylophagy & $8.20 \mathrm{a}$ & $5.70 \mathrm{~b}$ & $7.50 \mathrm{a}$ & 0.52 & 0.04 \\
\hline Liquid excretion & 4.70 & 4.60 & 3.50 & 0.54 & 0.63 \\
\hline Solid excretion & 4.60 & 5.20 & 4.10 & 0.24 & 0.20 \\
\hline
\end{tabular}

SEM - standard error of the mean.

${ }^{1}$ Diets = control: diet without the use of enzymes; EXP3066: enzymatic extract (Aspergillus oryzae $\times$ Trichoderma viride $\times$ Bacillus subtilis) with a predominant activity of amylase; NSPases: enzymatic complex (Enspira ${ }^{\circledR}$; JBS-United; Sheridan, IN, EUA) composed of enzymes with action on non-starch polysaccharides. a,b - Means followed by different letters in the same row are significantly different by Tukey test $(\mathrm{P} \leq 0.04)$.

Table 6 - Carcass characteristics of feedlot finishing yearling bulls fed an energy-dense diet and supplemented with enzymes

\begin{tabular}{|c|c|c|c|c|c|}
\hline \multirow{2}{*}{ Item } & \multicolumn{3}{|c|}{ Diet } & \multirow{2}{*}{ SEM } & \multirow{2}{*}{ P-value } \\
\hline & Control & EXP3066 & NSPases & & \\
\hline Hot carcass weight $(\mathrm{kg})$ & $290.4 b$ & $294.7 \mathrm{a}$ & $296.0 \mathrm{a}$ & 2.83 & 0.04 \\
\hline Carcass yield $(\%)$ & 56.84 & 56.77 & 56.72 & 0.35 & 0.99 \\
\hline Carcass length (cm) & 132.9 & 133.8 & 134.0 & 0.50 & 0.81 \\
\hline Top round diameter $(\mathrm{cm})$ & 21.58 & 20.83 & 21.04 & 0.15 & 0.38 \\
\hline Arm length $(\mathrm{cm})$ & 39.42 & 41.67 & 39.92 & 0.32 & 0.16 \\
\hline Arm circumference $(\mathrm{cm})$ & 41.08 & 43.08 & 43.42 & 0.44 & 0.30 \\
\hline \multicolumn{6}{|l|}{ Fat thickness (mm) } \\
\hline Longissimus dorsi & 4.500 & 4.330 & 4.250 & 0.08 & 0.65 \\
\hline Round & 5.170 & 4.830 & 4.920 & 0.11 & 0.67 \\
\hline Rib cage & 4.420 & 4.330 & 4.750 & 0.15 & 0.69 \\
\hline Chuck & 3.670 & 3.500 & 3.330 & 0.11 & 0.68 \\
\hline Top Sirloin & 7.890 & 7.709 & 8.262 & 0.33 & 0.78 \\
\hline Ribeye area $\left(\mathrm{cm}^{2}\right)$ & $84.76 b$ & $92.43 \mathrm{a}$ & $86.43 \mathrm{ab}$ & 1.21 & 0.03 \\
\hline Ratio & 0.485 & 0.477 & 0.492 & 0.01 & 0.28 \\
\hline Marbling & $2.555 \mathrm{~b}$ & $3.016 \mathrm{a}$ & $2.740 \mathrm{ab}$ & 0.08 & 0.07 \\
\hline
\end{tabular}

SEM - standard error of the mean.

${ }^{1}$ Diets = control: diet without the use of enzymes; EXP3066: enzymatic extract (Aspergillus oryzae $\times$ Trichoderma viride $\times$ Bacillus subtilis) with a predominant activity of amylase; NSPases: enzymatic complex (Enspira ${ }^{\circledR}$; JBS-United; Sheridan, IN, EUA) composed of enzymes with action on non-starch polysaccharides. $\mathrm{a}, \mathrm{b}$ - Means followed by different letters in the same row are significantly different by Tukey test $(\mathrm{P} \leq 0.07)$.

$(\mathrm{P}=0.03)$ and marbling $(\mathrm{P}=0.07)$ when compared with the control diet. However, no differences were found between EXP3066 and NSPases supplementations.

\section{Discussion}

The use of exogenous enzymes in ruminant nutrition has been identified as a possible strategy to increase digestibility and improve feed utilization efficiency
(Krueger et al., 2008; Tang et al., 2008; Meale et al., 2014). However, the effect of the supplementation with enzymes on animal performance has been inconsistent.

Beauchemin et al. (1999) reported a 7\% improvement in $\mathrm{G}: \mathrm{F}$ and a $9 \%$ improvement in ADG in feedlot steers fed diets supplemented with enzymes. McAllister et al. (1999), in a study with high-energy diets, also reported an improvement in performance (increased ADG by 9\%) in animals that received diets supplemented with enzymes (cellulases and hemicellulases). Several studies, however, showed no effect of enzyme supplementation on animal performance (ZoBell et al, 2000; Eun et al, 2009; DiLorenzo et al., 2011; Oliveira et al., 2015).

The inconsistency of results can be attributed, in part, to the differences in the activity and characteristics of the supplemental enzymes employed in each study, as well as the physical and chemical properties of the substrates, since each of the enzymes has its own individual substrate specificity (Beauchemin et al., 2004; Salem et al., 2012; Tadele and Animut, 2015).

Pursuant to this fact, Beauchemin et al. (1995) reported that mixtures of fibrolytic enzymes (xylanase and cellulase) added to alfalfa hay-based diets increased the ADG of steers, but no effect was found when the mixtures were added to barley silage. When evaluating the same enzymatic formulation of Beauchemin et al. (1995) in high-energy diets, Beauchemin et al. (1997) observed an improvement of $11 \%$ in the G:F of animals when the enzymes (high- and low-xylanase activity included in manufacturing at a rate of $4.0 \mathrm{~L} \mathrm{t}^{-1}$ of concentrate DM) were added to a barley grainbased diet; however, the performance of the animals was not affected when the mixture of enzymes was added to corn-based diet.

In the present study, there was a positive effect of enzyme supplementation on animal performance. In general, the performance improvement (average of 8.8\%) of the animals fed diet supplemented with NSPases complex was more pronounced compared with those fed diet supplemented with EXP3066 extract (average of $4.8 \%$ ), and only the NSPases complex was efficacious for improving the ADG, G:F, and CG:F of these animals. These results are possibly related to the greater quantity of substrates in the diet available for NSPases activity, as well as the higher enzymatic activity (IU/g) of the product itself. As Meale et al. (2014) reported, the amount of enzymes and substrates as well as the interaction between the two are important in improving feed utilization.

Several enzymes (xylanase, cellulase, $\beta$-glucanase, $\beta$-mannanase, and $\alpha$-galactosidase) with activity in NSP were found in the enzymatic complex NSPases composition, 
while in EXP3066 extract composition, only xylanase (9 IU/g) and amylase (107 IU/g) were found. According to Krause et al. (2003), Beauchemin et al. (2003), and Elghandour et al. (2015), the diversity of enzymes is advantageous as it facilitates the segmentation of several feed substrates. Collins et al. (2006) and Barletta (2010) reaffirmed that the enzymes cellulase, xylanase, and $\beta$-glucanase (present in NSPases complex composition) break the $\beta-1,4$ bond of cellulose, arabinoxylan, and $\beta$-glucan, respectively, which are the main NSP in corn grain.

According to Akin and Rigsby (2008) and Barletta (2010), NSP not only are less digestible, but they can also prevent the digestion of other carbohydrates (such as starch), proteins, and other nutrients, as these nutrients are encapsulated by NSP, thus preventing physical access of digestive enzymes. Therefore, the increased degradation of NSP present in the corn grain cellular wall can improve the utilization of other nutrients.

The starch and CP digestibilities were not affected by the use of enzymes in the present study; however, there was an improvement in apparent DM digestibility. Lower fecal whole grain residual percentage was also observed in animals fed the EXP3066 and NSPases supplementation. These results explain, in part, the observed improvement in the performance of the animals receiving supplementation with enzymes in the present study. Mendoza et al. (2013) also observed an improvement in DM digestibility in ruminants receiving a diet supplemented with enzymes. In their case, the addition of glucoamylases to a diet composed of a $45 \%$ corn and sorghum mix resulted in an increase of $4.13 \%$ in DM digestibility in lambs compared with animals fed the non-supplemented diet. Salem et al. $(2012,2013)$ also reported improvements in diet DM digestibility in ruminants (sheep and beef steers, respectively) receiving supplementation of a commercial mixture of exogenous enzymes (endoglucanase, xylanase, $\alpha$ - amylase, and protease activity). The same effect was observed in in situ (Krueger and Adesogan, 2008) and in vitro (Moharrery et al., 2009) studies. Nonetheless, the mechanism by which exogenous enzymes improve diet digestibility is still not fully understood. Several hypotheses, among them an increase in ruminal microbial colonization and adhesion to the surface of feedstuffs (Colombatto et al., 2003; Jalilvand et al., 2008), stimulation of ruminal microbial population and synergy with ruminal microbial enzymes (Morgavi et al., 2000; Tadele e Animut, 2015), and direct hydrolysis of substrates by the enzymes (Beauchemin et al., 2003; Moharrery et al., 2009), have been suggested.
Hristov et al. (2000) and McAllister et al. (2001) proposed a possible action of these enzymes in postruminal diet digestion. According to these authors, the exogenous enzymes can remain active in the lower gastrointestinal tract and, thus, could potentially contribute to post-ruminal digestion.

The NSPases complex contains enzymes originated from the fungi Aspergillus niger and Trichoderma reesei, which (especially those formed by the latter) possess an optimum pH range below 6.0 (Paloheimo et al., 2010) and, therefore, ensure a degree of activity in post-ruminal digestion. Furthermore, in energy-dense diets (as in the diet from the current study), it is expected that even in the rumen, the $\mathrm{pH}$ values are below typical levels that generally result in a decrease in the population of fibrolytic microorganisms (Brown et al., 2006; Fernando et al., 2010). Therefore, as the enzymes from the NSPases complex exhibit activity even at low $\mathrm{pH}$, those populations were probably unaffected, which may partially justify the improved performance observed in animals fed diet supplemented with this enzymatic complex.

According to McAllister et al. (2001), exogenous enzymes can also decrease the viscosity of the duodenal contents, which contribute to a greater digestion and absorption of nutrients. Hristov et al. (2000) reported decreased digesta viscosity in addition to the $30 \%$ increase in xylanase activity in the intestine when exogenous enzymes were added to the diet.

Paloheimo et al. (2010) highlighted that the enzymes provided a probiotic effect in addition to the beneficial characteristics mentioned above. Its mechanism would be based on breaking down the cellular wall and the transfer of nutrients, favoring the development of amylolytic bacteria, such as the Lactobacillus sp., which, as a result, would generate an increase in starch digestibility. However, in the present study, this probably did not occur, since the starch digestibility was not improved.

Nozière et al. (2014), when evaluating the effect of the use of exogenous amylolytic enzymes on the metabolism of dairy cattle fed diets containing high and low starch content, observed that the ruminal starch degradation was greater in the cows fed supplemented diet (81 vs. $75 \%$ ) compared with those of control. However, no effect in overall starch digestibility was observed, which may have also occurred in the present study.

According to Beauchemin et al. (2003), the increased protein digestibility with the use of enzymes in the diet may be attributed in part to the greater synthesis of microbial protein in the rumen. This however, was not observed in 
the current study as the $\mathrm{CP}$ digestibility was not different between treatments.

Therefore, the improved DM digestibility observed with the use of the enzymes may be attributed to enzyme activity affecting other components of the diet, such as NDF. This hypothesis is consistent with several other studies (Beauchemin et al., 1995; Feng et al., 1996; Martins et al., 2006; Klingerman et al., 2009 and Gencoglu et al., 2010) in which the authors associated the increase in diet digestibility to the increase in NDF digestibility. It is possible that the same happened in the present study, since no alteration in starch and CP digestibility was observed.

Regarding the behavioral variables, animals fed diet supplemented with EXP3066 spent less time in rumination and presented a reduced number of xylophagy events. The amount of time (h/day) spent eating was also affected by the enzyme supplementation, whereas the animals fed diet supplemented with NSPases complex spent less time eating. Despite this difference, there was no alteration in DMI of these animals. Bowman et al. (2003) did not observe differences in eating behavior of dairy cows fed diet supplemented with enzymes in different ways of administration.

The use of exogenous enzymes in animal nutrition is known to increase the concentrations of volatile fatty acids (Beauchemin et al., 2003), which can influence fat synthesis and carcass characteristics of animals fed supplemented diets (Vargas et al., 2013). However, there are few studies evaluating the effect of the use of enzymes in carcass variables.

Diet supplementation with exogenous enzymes increased the HCW values of animals compared with the non-supplemented diet. This result is possibly related to the increase in diet digestibility, in which the greater use of nutrients was reflected in greater carcass weight. Parsons et al. (2007) also observed higher carcass weight in animals fed diet supplemented with enzymes.

The supplementation with EXP3066 resulted in increased REA and marbling compared with the control diet. Tricarico et al. (2007) observed a quadratic increase in REA when evaluating increasing values of $\alpha$-amylase ( 0 , 580 , and $1160 \mathrm{DU} / \mathrm{kg}$ of DM) supplementation to feedlot cattle, which was attributed to the improvement in carcass weight gain of these animals.

There was no effect of the diet supplementation with exogenous enzymes on the other carcass variables evaluated. However, Vargas et al. (2013) found a quadratic increase in carcass yield when evaluating different concentrations $(0,2,4$, and $6 \mathrm{ppm})$ of an enzymatic complex (xylanases and cellulases) in the supplementation of confined cattle, with greater values from animals that received intermediate concentrations of enzymes.

According to Wallace et al. (2001) and Beauchemin et al. (2003), dosage is one of the main factors responsible for the ineffectiveness of enzymatic products. Too-low dosage levels are insufficient to produce an improvement in nutrient digestibility, whereas too-high dosage levels may compete with microorganism adhesion sites on the same substrate, thereby lowering its activity. According to these reports, together with the quadratic responses of different enzyme concentrations observed in the studies of Vargas et al. (2013) and Tricarico et al. (2007), future research should be considered to evaluate the effect of different concentrations of NSPases and EXP3066 supplementation.

\section{Conclusions}

Exogenous enzymes improve performance and carcass traits of feedlot cattle fed high-grain diet. However, these improvements are more relevant for animals fed NSPases complex.

\section{References}

Akin, D. E. and Rigsby, L. L. 2008. Corn fiber: composition, and response to enzymes for fermentable sugars and coproducts. Applied Biochemistry and Biotechnology 144:59-68. https://doi. org/10.1007/s12010-007-0053-0

AOAC - Association of Official Analytical Chemistry. 1995. Official methods of analysis. 16th ed. AOAC International, Arlington, VA.

Barletta, A. 2010. Introduction: current markets and expected development. p.1-11. In: Enzymes in farm animal nutrition. Bedford, M. and G. Partridge, eds. CAB International, Wallingford, UK.

Beauchemin, K. A.; Colombatto, D.; Morgavi, D. P. and Yang, W. Z. 2003. Use of exogenous fibrolytic enzymes to improve feed utilization by ruminants. Journal of Animal Science 81(suppl 2):E37-E47.

Beauchemin, K. A.; Colombatto, D.; Morgavi, D. P.; Yang, W. Z. and Rode, L. M. 2004. Mode of action of exogenous cell wall de-grading enzymes for ruminants. Canadian Journal of Animal Science 84:13-22. https://doi.org/10.4141/A02-102

Beauchemin, K. A.; Jones, S. D. M.; Rode, L. M. and Sewalt, V. J. H. 1997. Effects of fibrolytic enzyme in corn or barley diets on performance and carcass characteristics of feedlot cattle. Canadian Journal of Animal Science 77:645-653.

Beauchemin, K. A.; Rode, L. M. and Karren, D. 1999. Use of feed enzymes in feedlot finishing diets. Canadian Journal of Animal Science 79:243-246.

Beauchemin, K. A.; Rode, L. M. and Sewalt, V. J. H. 1995. Fibrolytic enzymes increase fiber digestibility and growth rate of steers fed dry forages. Canadian Journal of Animal Science 75:641-644. https://doi.org/10.4141/cjas95-096

Bowman, G. R.; Beauchemin, K. A. and Shelford, J. A. 2003. Fibrolytic enzymes and parity effects on feeding behavior, salivation, and ruminal $\mathrm{pH}$ of lactating dairy cows. Journal of Dairy Science 86:565-575. https://doi.org/10.3168/jds.S0022-0302(03)73635-2 
Brown, M. S.; Ponce, C. H. and Pulikanti, R. 2006. Adaptation of beef cattle to high-concentrate diets: Performance and ruminal metabolism. Journal of Animal Science 84(suppl 13):E25-E33. https://doi.org/10.2527/2006.8413_supplE25x

Colombatto, D.; Morgavi, D. P.; Furtado, A. F. and Beauchemin, K. A. 2003. Screening of exogenous enzymes for ruminant diets: Relationship between biochemical characteristics and in vitro ruminal degradation. Journal of Animal Science 81:2628-2638. https://doi.org/10.2527/2003.81102628x

Collins, T.; Gerday, C. and Feller, G. 2006. Xylanases, xylanase families and extremophilic xylanases. FEMS Microbiology Reviews 29:3-23. https://doi.org/10.1016/j.femsre.2004.06.005

Correa, C. E. S.; Shaver, R. D.; Pereira, M. N.; Lauer, J. G. and Kohn, K. 2002. Relationship between corn vitreousness and ruminal in situ starch degradability. Journal of Dairy Science 85:3008-3012. https://doi.org/10.3168/jds.S0022-0302(02)74386-5

DiLorenzo, N.; Smith, D. R.; Quinn, M. J.; May, M. L.; Ponce, C. H.; Steinberg, W.; Engstrom, M. A. and Galyean, M. L. 2011. Effects of grain processing and supplementation with exogenous amylase on nutrient digestibility in feedlot diets. Livestock Science 137:178-184. https://doi.org/10.1016/j.livsci.2010.11.003

Elghandour, M. M. M. Y.; Kholif, A. E.; Márquez-Molina, O.; Vázquez-Armijo, J. F.; Puniya, A. K. and Salem, A. Z. M. 2015. Influence of individual or mixed cellulase and xylanase mixtures on in vitro rumen gas production kinetics of total mixed rations with different maize silage and concentrate ratios. Turkish Journal of Veterinary and Animal Sciences 39:1410-1426.

Eun, J. S.; ZoBell, D. R.; Dschaak, C. M.; Diaz, D. E. and Tricarico, J. M. 2009. Case study: Effects of supplementing a fibrolytic feed enzyme on the growth performance and carcass characteristics of beef steers. Professional Animal Scientist 25:382-387. https://doi.org/10.15232/S1080-7446(15)30729-4

Feng, P.; Hunt, C. W.; Pritchard, G. T. and Julien, W. E. 1996. Effect of enzyme preparations on in situ and in vitro degradation and in vivo digestive characteristics of mature cool-season grass forage in beef steers. Journal of Animal Science 74:1349-1357.

Fernando, S. C.; Purvis II, H. T.; Najar, F. Z.; Sukharnikov, L. O.; Krehbiel, C. R.; Nagaraja, T. G.; Roe, B. A. and Desilva, U. 2010. Rumen microbial population dynamics during adaptation to a high-grain diet. Applied and Environmental Microbiology 76:7482-7490. https://doi.org/10.1128/AEM.00388-10

Gencoglu, H.; Shaver, R. D.; Steinberg, W.; Ensink, J.; Ferraretto, L. F.; Bertics, S. J. and Akins, M. 2010. Effect of feeding a reduced-starch diet with or without amylase addition on lactation performance in dairy cows. Journal of Dairy Science 93:723-732. https://doi.org/10.3168/jds.2009-2673

Goering, H. K. and Van Soest, P. J. 1970. Forage fiber analysis: apparatus reagents, procedures and some applications. Agricultural Handbook No. 379. ARS-USDA, Washington, DC.

Hendrix, D. L. 1993. Rapid estraction and analyses of nonstructural carbohydrates in plant tissues. Crop Science 33:1306-1311. https://doi.org/10.2135/cropsci1993.0011183X003300060037x

Herring, W. O.; Miller, D. C.; Bertrand, J. K. and Benyshek, L. L. 1994. Evaluation of machine, technician and interpreter effects on ultrasonic measures of backfat and longissimus muscle area in beef cattle. Journal of Animal Science 72:2216-2226.

Hristov, A. N.; McAllister, T. A. and Cheng, K. J. 2000. Intraruminal supplementation with increasing levels of exogenous polysaccharide-degrading enzymes: effects on nutrient digestion in cattle fed a barley grain diet. Journal of Animal Science 78:477-487. https://doi.org/10.2527/2000.782477x

Jalilvand, G.; Odongo, N. E.; López, S.; Naserian, A.; Valizadeh, R.; Shahrodi, F. E.; Kebreab, E. and France, J. 2008. Effects of different levels of an enzyme mixture on in vitro gas production parameters of contrasting forages. Animal Feed Science and Technology 146:289-301. https://doi.org/10.1016/j.anifeedsci.2008.01.007
Johnson, T. R. and Combs, D. K. 1991. Effects of pre partum diet, inert rumen bulk, and dietary polyethylene glycol on dry matter intake of lactating dairy cows. Journal of Dairy Science 74:933-944.

Klingerman, C. M.; Hu, W.; McDonell, E. E.; DerBedrosian, M. C. and Kung Jr, L. 2009. An evaluation of exogenous enzymes with amylolytic activity for dairy cows. Journal of Dairy Science 92:1050-1059. https://doi.org/10.3168/jds.2008-1339

Krause, D. O.; Denman, S. E.; Roderick, I. M.; Marrison, M.; Rae, A. L.; Attwood, G. T. and McSweeney, S. 2003. Opportunities to improve fibre degradation in the rumen: Microbiology, ecology, and genomics. FEMS Microbiology Reviews 27:663-693.

Krueger, N. A. and Adesogan, A. T. 2008. Effects of different mixtures of fibrolytic enzymes on digestion and fermentation of bahiagrass hay. Animal Feed Science and Technology 145:84-94. https://doi. org/10.1016/j.anifeedsci.2007.05.041

Krueger, N. A.; Adesogan, A. T.; Staples, C. R.; Krueger, W. K.; Kim, S. C.; Littell, R. C. and Sollenberger, L. E. 2008. Effect of method of applying fibrolytic enzymes or ammonia to Bermudagrass hay on feed intake, digestion, and growth of beef steers. Journal of Animal Science 86:882-889. https://doi.org/10.2527/jas.2006-717

Martins, A. S.; Vieira, P. F.; Berchielli, T. T.; Prado, I. N. and Moletta, J. L. 2006. Consumo e digestibilidade aparente total em bovinos sob suplementação com enzimas fibrolíticas. Revista Brasileira de Zootecnia 35:2118-2124. https://doi.org/10.1590/S151635982006000700032

McAllister, T. A.; Hristov, A. N.; Beauchemin, K. A.; Rode, L. M. and Cheng, K. J. 2001. Enzymes in ruminants diets. In: Enzymes in farm animal nutrition. Bed-ford, M. R. and Partridge, G. G., eds. CAB International, Wiltshire, UK.

McAllister, T. A.; Oosting, S. J.; Popp, J. D.; Mir, Z.; Yanke, L. J.; Hristov, A. N.; Treacher, R. J. and Cheng, K. J. 1999. Effect of exogenous enzymes on digestibility of barley silage and growth performance of feedlot cattle. Canadian Journal of Animal Science 79:353-360. https://doi.org/10.4141/A98-099

Meale, S. J.; Beauchemin, K. A.; Hristov, A. N.; Chaves, A. V. and McAllister, T. A. 2014. Board-invited review: opportunities and challenges in using exogenous enzymes to improve ruminant production. Journal of Animal Science 92:427-442. https://doi.org/10.2527/jas.2013-6869

Mendoza, G. D.; Mota, N.; Plata, F. X.; Martinez, J. A. and Hernández, P. A. 2013. Effects of exogenous glucoamylase from Aspergillus niger and grain level on performance of the lambs. Animal Nutrition and Feed Technology 13:391-398.

Millen, D. D.; Pachecho, R. D. L.; Arrigoni, M. D. B.; Galyean, M. L. and Vasconcelos, J. T. 2009. A snapshot of management practices and nutritional recommendations used by feedlot nutritionists in Brazil. Journal of Animal Science 87:3427-3439. https://doi.org/10.2527/jas.2009-1880

Moharrery, A.; Hvelplund, T. and Weisbjerg, M. R. 2009. Effect of forage type, harvesting time and exogenous enzyme application on degradation characteristics measured using in vitro technique. Animal Feed Science and Technology 153:178-192. https://doi.org/10.1016/j.anifeedsci.2009.06.001

Morgavi, D. P.; Beauchemin, K. A.; Nsereko, V. L.; Rode, L. M.; Iwaasa, A. D.; Yang, W. Z.; McAllister, T. A. and Wang, Y. 2000. Synergy between ruminal fibrolytic enzymes and enzymes from Trichoderma longibrachiatum. Journal of Dairy Science 83:1310-1321. https://doi.org/10.3168/jds.S0022-0302(00)74997-6

Müller, L. 1987. Normas para avaliação de carcaças e concurso de carcaças de novilhos. Universidade Federal de Santa Maria, Departamento de Zootecnia, Santa Maria. 
Neumann, M.; Leão, G. F. M.; Horst, E. H.; Figueira, D. N. and Ribas, T. M. B. 2015. Desempenho de novilhos holandeses recriados com dietas $100 \%$ concentrado inteiramente peletizada ou não. Revista Científica de Produção Animal 17:76-83.

Nozière, P.; Steinberg, W.; Silberberg, M. and Morgavi, D. P. 2014. Amylase addition increases starch ruminal digestion in firstlactation cows fed high and low starch diets. Journal of Dairy Science 97:2319-2328. https://doi.org/10.3168/jds.2013-7095

NRC - National Research Council. 2000. Nutrient requirements of beef cattle. 7th rev. ed. National Academic Press, Washington, DC.

Oliveira, L. G.; Ferreira, R. N.; Padua, J. T.; Ulhoa, C. J.; Cysneiros, C. S. S. and Arnhold, E. 2015. Performance of beef cattle bulls in feed lots and fed on diets containing enzymatic complex. Acta Scientiarum, Animal Science 37:181-186. https://doi.org/10.4025/ actascianimsci.v37i2.26446

Paloheimo, M.; Piironen, J. and Vehmaanoerä, J. 2010. Xylanases and cellulases as feed additives. p.12-53. In: Enzimes in farm animal nutrition. Bedford, M. R. and Partridge, G. G., eds. CAB International.

Parsons, C. H.; Vasconcelos, J. T.; Swingle, R. S.; Defoor, P. J.; Nunnery, G. A.; Salyer, G. B. and Galyean, M. L. 2007. Effects of wet corn gluten feed and roughage levels on performance, carcass characteristics, and feeding behavior of feedlot cattle. Journal of Animal Science 85:3079-3089. https://doi.org/10.2527 /jas.2007-0149

Salem, A. Z. M.; Hassan, A. A.; Gado, H. M.; Colombatto, D. B. and Eghandour, M. M. Y. 2013. Effect of exogenous enzymes on nutrient digestibility, ruminal fermentation and growth performance in beef steers. Livestock Science 154:69-73.

Salem, A. Z. M.; Hassan, A. A.; Gado, H. M.; Khalil, M. S.; Simbaya, J. and Alsarsy, H. 2012. Effect of sun-drying and exogenous enzymes on nutrients intake and digestibility as well as nitrogen utilization in sheep fed Atriplex halimus foliages. Animal Feed Science and Technology 171:128-135.
Tadele, Y. and Animut, G. 2015. Effect of exogenous enzymes on ruminal degradation of feed and animal performance: a review. Advances in Life Science and Technology 28:2224-7181.

Tang, S. X. G.; Tayo, O.; Tan, Z. L.; Sun, Z. H.; Shen, L. X.; Zhou, C. S.; Xiao, W. J.; Ren, G. P.; Han, X. F. and Shen, S. B. 2008. Effects of yeast culture and fibrolytic enzymes supplementation on in vitro fermentation characteristics of low-quality cereal straws. Journal of Animal Science 86:1164-1172.

Tricarico, J. M.; Abney, M. D.; Galyean, M. L.; Rivera, J. D.; Hanson, K. C.; McLeod, K. R. and Harmon, D. L. 2007. Effects of a dietary Aspergillus oryzae extract containing $\alpha$-amylase activity on performance and carcass characteristics of finishing beef cattle. Journal of Animal Science 85:802-811. https://doi.org/10.2527/jas.2006-427

Van Soest, P. J.; Robertson, J. B. and Lewis, B. A. 1991. Symposium: Carbohydrate methodology, metabolism, and nutritional implications in dairy cattle. Methods for dietary fiber, neutral detergent fiber, and nonstarch polysaccharides in relation to animal nutrition. Journal of Dairy Science 74:3583-3597.

Vargas, J.; Mendoza, G. D.; De la Salud Rubio-Lozano, M. and Castrejón, F. A. 2013. Effect of exogenous fibrolytic enzymes on the carcass characteristics and performance of grain-finished steers. Animal Nutrition and Feed Technology 13:435-439.

Wallace, R. J.; Wallace, S. J.; McKain, N.; Nsereko, V. L. and Hartnell, G. F. 2001. Influence of supplementary fibrolytic enzymes on the fermentation of corn and grass silages by mixed ruminal microorganisms in vitro. Journal of Animal Science 79:1905-1916.

Weiss, W. P.; Conrad, H. R. and Pierre, N. R. 1992. A theoretically based model for predicting total digestible nutrient values of forages and concentrates. Animal Feed Science and Technology 39:95-110. https://doi.org/10.1016/0377-8401(92)90034-4

ZoBell, D. R.; Weidmeier, R. D.; Olson, K. C. and Treacher, R. J. 2000. The effect of an exogenous enzyme treatment on production and carcass characteristics of growing and finishing steers. Animal Feed Science and Technology 87:279-285. https://doi.org/10.1016/ S0377-8401(00)00202-9 